Article

\title{
Atractylenolide-I Protects Human SH-SY5Y Cells from 1-Methyl-4-Phenylpyridinium-Induced Apoptotic Cell Death
}

\author{
Sandeep Vasant More and Dong-Kug Choi * \\ Department of Biotechnology, College of Biomedical and Health Science, Konkuk University, Chungju 380-701, \\ Korea; sandeepbcp@gmail.com \\ * Correspondence: choidk@kku.ac.kr; Tel.: +82-43-840-3610
}

Academic Editors: José L. Quiles and Maurizio Battino

Received: 24 January 2017; Accepted: 3 May 2017; Published: 8 May 2017

\begin{abstract}
Oxidative stress and apoptosis are the major mechanisms that induce dopaminergic cell death. Our study investigates the protective effects of atractylenolide-I (ATR-I) on 1-methyl-4-phenylpyridinium (MPP ${ }^{+}$-induced cytotoxicity in human dopaminergic SH-SY5Y cells, as well as its underlying mechanism. Our experimental data indicates that ATR-I significantly inhibits the loss of cell viability induced by MPP ${ }^{+}$in SH-SY5Y cells. To further unravel the mechanism, we examined the effect of ATR-I on $\mathrm{MPP}^{+}$-induced apoptotic cell death characterized by an increase in the Bax/Bcl-2 mRNA ratio, the release of cytochrome-c, and the activation of caspase-3 leading to elevated levels of cleaved poly(ADP-ribose) polymerase (PARP) resulting in SH-SY5Y cell death. Our results demonstrated that ATR-I decreases the level of pro-apoptotic proteins induced by $\mathrm{MPP}^{+}$and also restored Bax/Bcl-2 mRNA levels, which are critical for inducing apoptosis. In addition, ATR-I demonstrated a significant increase in the protein expression of heme-oxygenase in $\mathrm{MPP}^{+}$-treated SH-SY5Y cells. These results suggest that the pharmacological effect of ATR-I may be, at least in part, caused by the reduction in pro-apoptotic signals and also by induction of anti-oxidant protein.
\end{abstract}

Keywords: atractylenolide-I; apoptosis; $\mathrm{MPP}^{+}$; neuroprotection; Parkinson's disease

\section{Introduction}

A new flow of information indicates that oxidative stress induced by reactive oxygen species (ROS) is involved in selective nigral cell degeneration [1]. Postmortem studies of Parkinson's disease (PD) patients have provided evidence for chemical changes that are indicative of oxidative stress in the substantia nigra (SN) [2-4]. Neurons are highly sensitive to ROS, which are well-known triggers of programmed cell death. It is well established that human neurodegenerative pathologies, including stroke, Alzheimer's disease, and PD, involves several signaling pathways [5] fueled by oxidative stress leading to neuronal loss. The intrinsic mitochondrial signaling pathway is also involved in executing cell death initiated by 1-methyl-4-phenyl-2,3,6-tetrahydropyridine (MPTP) [6].

Experimental use of 1-methyl-4-phenylpyridinium $\left(\mathrm{MPP}^{+}\right)$in animal and cellular models is very well known to induce symptoms closely resembling $\mathrm{PD}$ [7]. $\mathrm{MPP}^{+}$is the active metabolite of MPTP, which accumulates within dopaminergic neurons up to millimolar concentration in the mitochondria, and selectively inhibits nicotinamide adenine dinucleotide coenzyme (NADH Co) Q1 reductase (complex I) of the mitochondrial electron transport chain [8]. Inhibition of complex-I increases the shunting of electrons through complex-II, which generates 5-7 times more ROS [9]. A decrease in mitochondrial complex-I activity primes Bax-dependent neuronal apoptosis through mitochondrial oxidative damage [10]. It is also documented that neuronal cell death induced by $\mathrm{MPP}^{+}$ is mediated by the opening of the mitochondrial permeability transition pore and the collapse of 
the mitochondrial membrane potential [11]. Additionally, the members of Bcl-2 family also play a significant role in $\mathrm{MPP}^{+}$-induced apoptotic cell death [12]. As reported, the death of dopaminergic neurons by apoptosis might be initiated by oxidative stress and neuroinflammation [13,14]. Apoptosis induced by oxidative stress is associated with the release of cytochrome c, activation of caspases, and cleavage of poly(ADP-ribose) polymerase (PARP) [15-17]. Therefore, inhibition of pro-apoptotic signaling molecules, along with ROS, may have therapeutic benefits for protecting dopaminergic neurons in PD.

Hence, there is a need to develop new protective agents that can avoid the succession of such neuronal apoptosis. Extracts from medicinal plants, secondary metabolites, and their bioactive ingredients have conventionally been used to treat numerous neurodegenerative diseases [18]. Information from various reports have documented that several oriental herbs from plants, or nutrients from foods, have protective activity against apoptosis and are potential therapeutic agents [19]. Lately, there has been a growing interest in research concerning natural products due to the failure of substitute drug discovery methods to deliver many leading compounds in key therapeutic areas [20]. Hence, the industry in the pharmaceutical segment is focused on developing new drugs based on natural sources through the examination of leads from the traditional systems of medicine [20]. In our current study, we have used atractylenolide-I (ATR-I); an active principle obtained from rhizomes of Atractylodes macrocephala belonging to the Asteraceae family. Pharmacological studies have designated numerous activities of ATR-I in biological systems, such as gastrointestinal inhibitory effects [21], anti-oxidant activity [22], anti-inflammatory activity and anti-cancer activity [23,24]. Based on those reports of ATR-I we hypothesized that ATR-I might be a neuroprotective agent in $\mathrm{MPP}^{+}$-induced neuronal damage by inhibiting oxidative stress and apoptotic cell death. We, therefore, explored the therapeutic potential of ATR-I, and explored possible mechanisms in the MPP+-induced PD model in SH-SY5Y cells.

\section{Results}

\subsection{Effects of Atractylenolide-I (ATR-I) on Cytotoxicity Induced by 1-Methyl-4-Phenylpyridinium $\left(M P P^{+}\right)$in} SH-SY5Y Cells

To investigate whether ATR-I causes mortality in SH-SY5Y cells, they were incubated with various concentrations of ATR-I $(1,5,25,50$ and $100 \mu \mathrm{M})$ for $24 \mathrm{~h}$ (Figure 1A). Our results indicated that ATR-I $(1,5,25 \mu \mathrm{M})$ did not show any significant cytotoxicity in SH-SY5Y cells for $24 \mathrm{~h}$. While the higher doses (50 and $100 \mu \mathrm{M}$ ) were observed to significantly decrease cell viability. Furthermore, we tested the effect of ATR-I $(1,5$ and $25 \mu \mathrm{M})$ in combination with $2 \mathrm{mM} \mathrm{MPP}^{+}$. As illustrated in Figure 1B, $\mathrm{MPP}^{+}$-induced a significant decrease $(48 \%)$ in cell viability as compared to the vehicle group. However, pre-incubation with ATR-I (1, 5 and $25 \mu \mathrm{M})$ prevented cells from $\mathrm{MPP}^{+}$-induced cell damage by dose-dependently restoring cell viability to $56.50 \%, 60.49 \%$, and $71.49 \%$ in comparison to $\mathrm{MPP}^{+}$group.
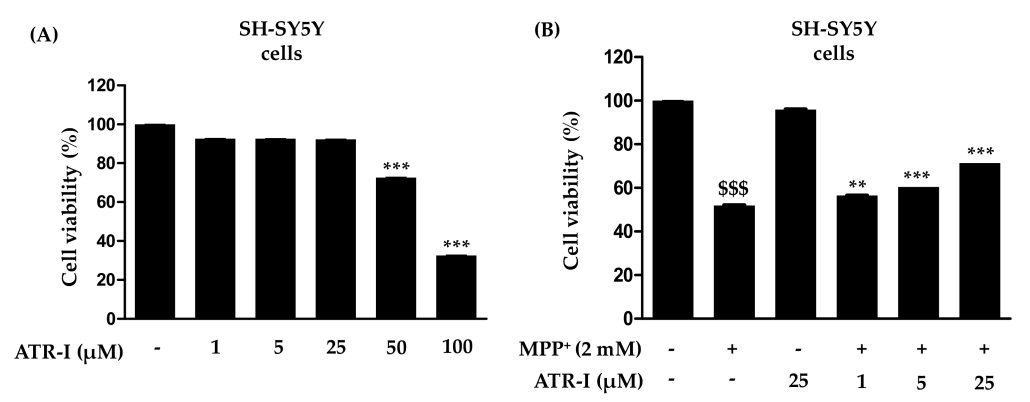

Figure 1. (A,B) Effects of atractylenolide-I (ATR-I) on cell viability in SH-SY5Y cells intoxicated with or without 1-methyl-4-phenylpyridinium $\left(\mathrm{MPP}^{+}\right)$. The viability of cells was performed as mentioned in the "Material and Method" section. ${ }^{* *} p<0.001$ vs. vehicle group. ${ }^{\$ \$ \$} p<0.001$ vs. vehicle group, and ${ }^{* * *} p<0.001,{ }^{* *} p<0.01$ vs. $\mathrm{MPP}^{+}$-treated group. 
2.2. ATR-I Abates Bax, Bcl-2 Ratios and Upregulates Heme Oxygenase (HO-1) mRNA and Protein Expression in MPP ${ }^{+}$-Intoxicated SH-SY5Y Cells

As shown in Figure 2A, exposure to $\mathrm{MPP}^{+}$significantly increases Bax mRNA expression (nine-fold) in comparison to the control group, a finding which is consistent with previous reports $[25,26]$, while pre-treatment with ATR-I $(1 \mu \mathrm{M}(39 \%), 5(15 \%) \mu \mathrm{M}$ and $25(12 \%) \mu \mathrm{M})$ dose-dependently decreases Bax mRNA expression in comparison to $\mathrm{MPP}^{+}$-intoxicated cells. In contrast to Bax, the levels of Bcl-2 mRNA decreased (2-fold) in the $\mathrm{MPP}^{+}$-treated group as compared to the control group. These levels were dose-dependently increased after ATR-I treatment (1 (3.7-fold), 5 (4.57-fold), and 25 (7.2-fold) $\mu \mathrm{M})$ in comparison to $\mathrm{MPP}^{+}$-intoxicated cells. The Bax/Bcl-2 ratio in cells exposed to $2 \mathrm{mM} \mathrm{MPP}$ was 12-fold higher than the control group, while in cells pre-treated with 1, 5 and $25 \mu \mathrm{M}$ ATR-I, the ratio decreased (11, 33 and 67-fold) in a dose-dependent fashion, suggesting that ATR-I treatment shifted the balance between pro- and anti-apoptotic members towards cell survival (Figure 2A). ATR-I treatment alone did not significantly alter the Bax/Bcl-2 ratio. Exposure to $2 \mathrm{mM} \mathrm{MPP}^{+}$was found to decrease the mRNA levels (3.2-fold) of heme oxygenase (HO-1) as compared to control group in SH-SY5Y cells. However, this decrease was reversed by pre-treatment with ATR-I $(25 \mu \mathrm{M})$ by three-fold in comparison to $\mathrm{MPP}^{+}$-intoxicated cells, respectively (Figure 2B). On the other hand, our data in Figure 2C, correlates with the dose-dependent rise (1 (1.2-fold), 5 (two-fold), and 25 (three-fold) $\mu \mathrm{M}$ ) in the protein expression profile of HO-1 by ATR-I in MPP ${ }^{+}$-stimulated SH-SY5Y cells. Thus, induction of HO-1 expression by ATR-1 suggests a role for an antioxidant mechanism in the protection of neuronal cells against $\mathrm{MPP}^{+}$-dependent cytotoxicity.

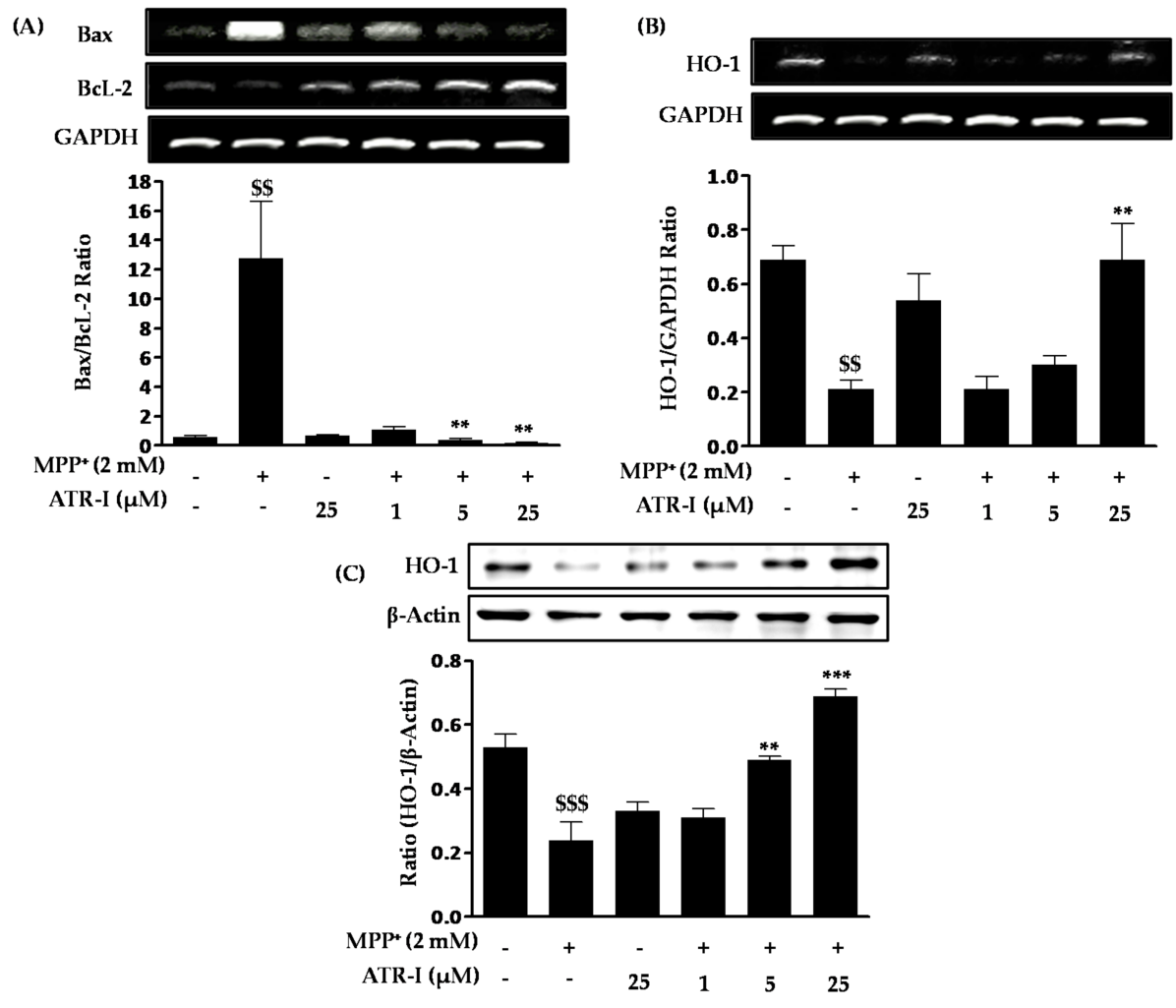

Figure 2. (A) Effects of ATR-I on the Bax/Bcl-2 mRNA ratio in $\mathrm{MPP}^{+}$-stimulated SH-SY5Y cells. The levels of (B) HO-1 mRNA and (C) HO-1 protein expression were quantitated by densitometric analysis. Quantification data are shown in the lower panel. Glyceraldehyde-3-phosphate dehydrogenase (GAPDH) and $\beta$-actin were used as internal controls. $\$ \$ \$<0.001$ and $\$ \$<<0.01$ vs. the vehicle group; *** $p<0.001$ and ${ }^{* *} p<0.01$ vs. the $\mathrm{MPP}^{+}$-treated group. 
2.3. ATR-I Pre-Treatment Mitigates MPP+-Induced Protein Expression of $p 53$ and Cytochrome-c in SH-SY5Y Cells

As shown in Figure $3 \mathrm{~A}, \mathrm{MPP}^{+}$treatment resulted in a significant increase (six-fold) in the levels of p53 in SH-SY5Y cells as compared to the control. Pre-treatment with various doses of ATR-I (1, (1.5-fold), 5 (2-fold), and 25 (7.5-fold) $\mu \mathrm{M}$ ) dose-dependently decreased protein levels of p53 in comparison to $\mathrm{MPP}^{+}$-intoxicated cells. Additionally, as seen in Figure 3B, exposure of $\mathrm{MPP}^{+}$to SH-SY5Y cells significantly increased the levels of cytochrome-c (2.5-fold) as compared to the control group. Pre-treatment of ATR-I (1 (1.2-fold), 5 (1.3-fold), and 25 (33-fold) $\mu \mathrm{M})$ was found to reduce the levels of cytochrome-c in comparison to $\mathrm{MPP}^{+}$-intoxicated cells.

(A)
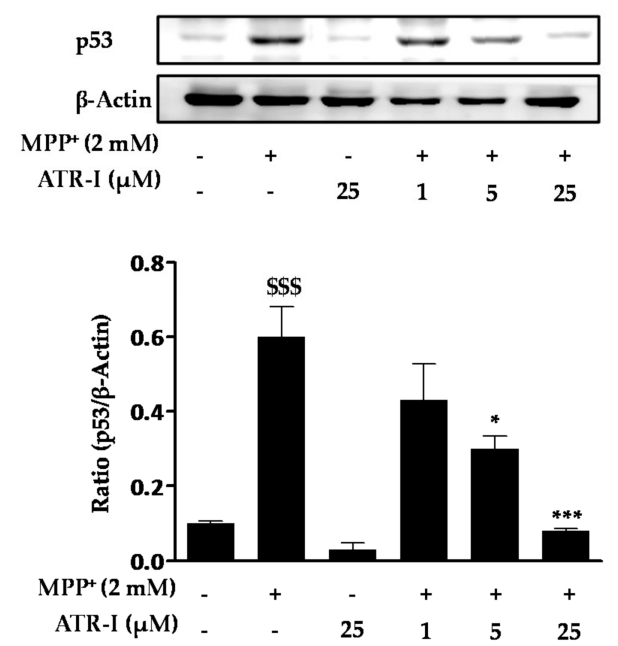

(B)
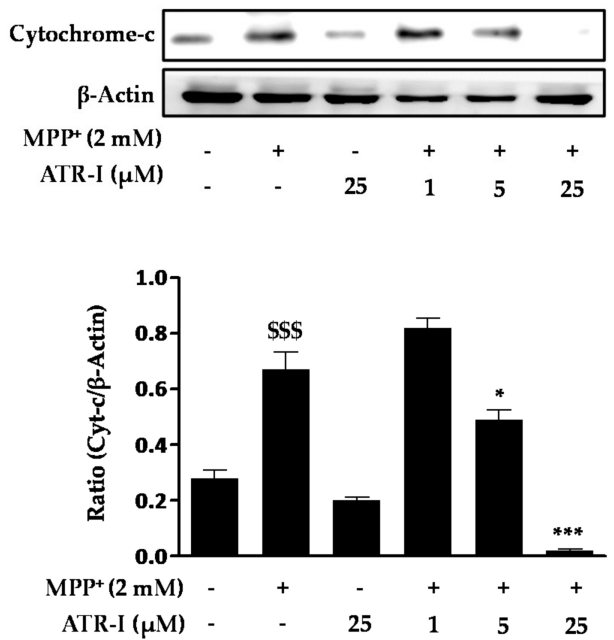

Figure 3. Effect of ATR-I on the MPP+-induced p53 and cytochrome-c release in SH-SY5Y cells. SH-SY5Y cells were subjected to Western blotting with specific antibodies for p53 (A) and cytochrome-c (B). Quantification of the relative expression of p53 and cytochrome-c is provided in the bar graph. $\beta$-actin was used as an internal control. $\$ \$ \$ p<0.001$ vs. the vehicle group; ${ }^{* * *} p<0.001$ and ${ }^{*} p<0.05$ vs. the $\mathrm{MPP}^{+}$-treated group.

\subsection{ATR-I Pre-Treatment Prevents MPP'-Induced Induction of Caspase-3 and Cleaved Poly(ADP-Ribose)} Polymerase (PARP) in SH-SY5Y Cells

Exposure of MPP ${ }^{+}$to SH-SY5Y cells significantly increased (3-fold) the protein levels of caspase-3 (Figure 4A) as compared to the control group. However, pre-treatment with ATR-I was successful in dose-dependently reversing (1 (1.4-fold), 5 (two-fold), and 25 (4.7-fold) $\mu \mathrm{M}$ ) the increased levels caspase-3 in comparison to $\mathrm{MPP}^{+}$intoxicated cells. Furthermore, $\mathrm{MPP}^{+}$was found to markedly increase (15-fold) the protein levels of cleaved PARP (Figure 4B) as compared to the control group. However, only the highest dose $(25 \mu \mathrm{M})$ of ATR-I decreased the levels of cleaved PARP (five-fold) as compared to the $\mathrm{MPP}^{+}$group. Lower doses of ATR-I $(1$ and $5 \mu \mathrm{M})$ were not observed to decrease the levels of cleaved PARP (1.1- and 1.5-fold). 
(A)
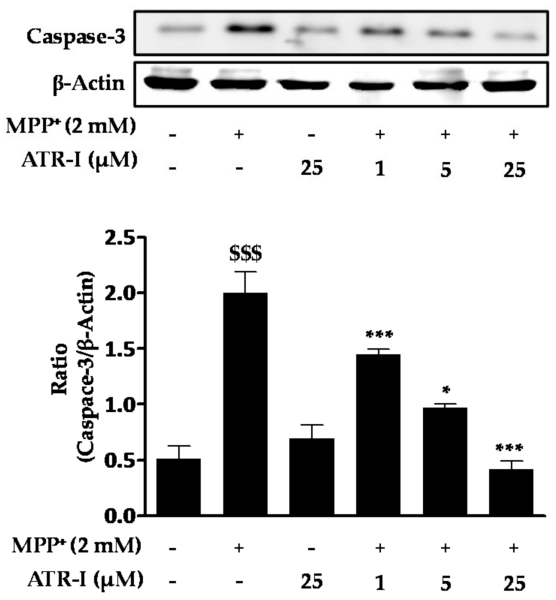

(B)
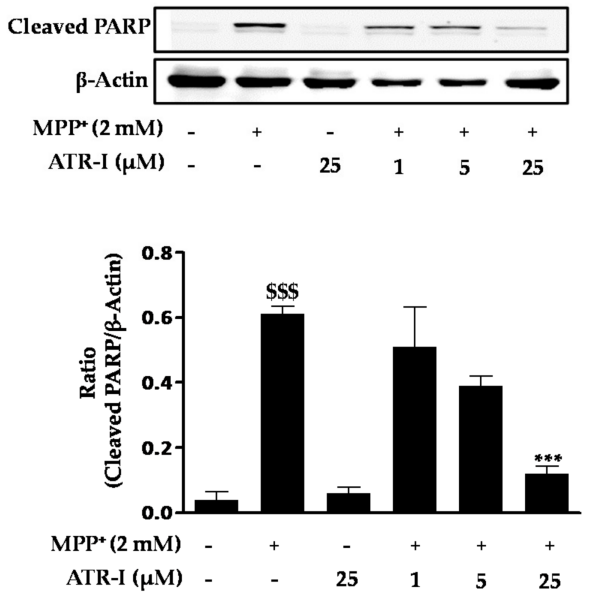

Figure 4. Effect of ATR-I on $\mathrm{MPP}^{+}$-induced expression of caspase-3 and cleaved poly(ADP-ribose) polymerase (PARP) in SH-SY5Y cells. SH-SY5Y cells were tagged with specific antibodies for caspase-3 (A) and cleaved PARP (B). Quantification of relative expression of caspase-3 and cleaved PARP is provided in the bar graph. $\beta$-actin was used as an internal control. $\$ \$ \$<0.001$ vs. the vehicle group; *** $p<0.001$ and $* p<0.05$ vs. the $\mathrm{MPP}^{+}$-treated group.

\subsection{Protective Role of HO-1 in MPP+-Intoxicated SH-SY5Y Cells}

As presented in Figure 5, sole treatment with either $\mathrm{MPP}^{+}$or zinc protoporphyrin-IX (ZnPP-IX) reduces the cell viability (56-57\%) to a significant extent in comparison to the vehicle group, while a combination of ZnPP-IX (5 $\mu \mathrm{M})$ and $2 \mathrm{mM} \mathrm{MPP}^{+}$aggravates the cytotoxicity $(8 \%)$ in SH-SY5Y cells in comparison to the vehicle group. Additionally, there is a significant difference in cell viability between $\mathrm{MPP}^{+}$relative to $\mathrm{MPP}^{+} / \mathrm{ATR}-\mathrm{I}$ and $\mathrm{MPP}^{+} / \mathrm{ATR}-\mathrm{I}$ relative to $\mathrm{MPP}^{+} / \mathrm{ZnPP}-\mathrm{IX} / \mathrm{ATR}-\mathrm{I}$. Pre-treatment with ATR-I $(25 \mu \mathrm{M})$ to cells exposed with ZnPP-IX $(5 \mu \mathrm{M})+2 \mathrm{mM} \mathrm{MPP}^{+}$was found to increase (three-fold) the cell viability to a significant extent in comparison to the ZnPP-IX $+\mathrm{MPP}^{+}$-treated group. This data suggests that HO-1 plays an important role in protecting the SH-SY5Y cells against $\mathrm{MPP}^{+}$-induced cell death.

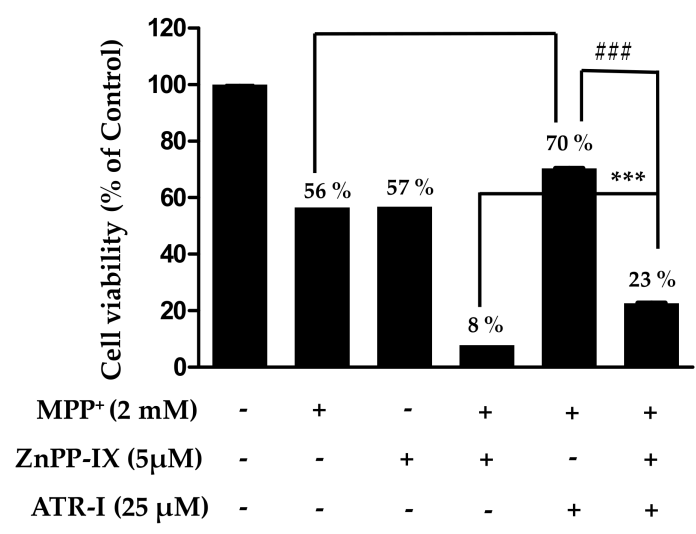

Figure 5. SH-SY5Y cells were pre-incubated with or without zinc protoporphyrin-IX (ZnPP-IX ) $(5 \mu \mathrm{M})$ for $2 \mathrm{~h}$ before treating them with ATR $(25 \mu \mathrm{M})$ for another $2 \mathrm{~h}$. Cells were further exposed to $2 \mathrm{mM} \mathrm{MPP}^{+}$ for $24 \mathrm{~h}$. Cell viability was measured by MTT assay. ${ }^{\$ \$} p<0.001$ vs. the $\mathrm{MPP}^{+}$group, ${ }^{\# \# \#} p<0.001$ vs. the $\mathrm{MPP}^{+}+\mathrm{ATR}-\mathrm{I}$ group and ${ }^{* * *} p<0.001$ vs. the $\mathrm{ZnPP}-\mathrm{IX}+\mathrm{MPP}^{+}$-treated group. 


\section{Discussion}

It is well accepted that many neurodegenerative diseases are mediated, at least in part, by apoptosis and oxidative stress. A variety of mechanisms that lead to apoptosis have been extensively characterized in a wide range of neuronal types. Mitochondria are a critical starting point for a multitude of apoptotic insults initiating a process described as the intrinsic death pathway [27]. Conflicting evidence has been presented as to which particular steps are essential for initiation of intrinsic neuronal apoptosis [28]. $\mathrm{MPP}^{+}$-treated dopaminergic human SH-SY5Y neuroblastoma cells are an established model to study neuronal apoptosis that has been widely used to study the neurodegenerative events that occur in PD. In our preliminary experiments, we found $2 \mathrm{mM} \mathrm{MPP}^{+}$ and an incubation time of $24 \mathrm{~h}$ were the optimal concentration and time for the induction of deleterious effects on cell viability of SH-SY5Y cells, which was in agreement with previous research [29]. In the present study, using undifferentiated SH-SY5Y cells, which are more susceptible to MPP+-induced cell death [30], we demonstrated that pre-treatment with ATR-I protected SH-SY5Y cells against $\mathrm{MPP}^{+}$-induced cytotoxicity by multiple lines of evidence.

There is increasing evidence that oxidative stress plays a key role in the pathogenesis of PD [31]. $\mathrm{MPP}^{+}$has been shown to cause neuronal cell death by inducing mitochondrial dysfunction and increasing ROS production [32]. ROS over-production can severely disrupt the mitochondrial membrane potential, resulting in the release of pro-apoptosis factors and neuronal cell death. HO-1 is an anti-oxidant and anti-apoptotic protein that is induced against oxidative stress [33]. Induction of HO-1 has been demonstrated to attenuate glutamate-induced apoptosis [34]. Hence, to unravel the protective role of HO-1, we have used ZnPP-IX (a specific inhibitor of HO-1) in our study. Only treatment with $25 \mu \mathrm{M}$ ATR-I was not observed to significantly increase mRNA and protein expression of HO-1 in SH-SY5Y cells. However, a combination of ATR-I with MPP ${ }^{+}$in SH-SY5Y cells significantly induced mRNA (ATR-I at $25 \mu \mathrm{M}$ ) and protein expression (ATR-I at 5 and $25 \mu \mathrm{M}$ ) of HO-1 in SH-SY5Y cells. Furthermore, ZnPP-IX, was observed to decrease cell viability comparable to that elicited by $\mathrm{MPP}^{+}$-treatment. Combination treatment of $\mathrm{ZnPP}-\mathrm{IX}+\mathrm{MPP}^{+}$decreased the cell viability to a greater extent as compared to the $\mathrm{MPP}^{+}$group, per se. Pre-treatment with ATR-I was found to significantly increase the cell viability in the $\mathrm{ZnPP}+\mathrm{MPP}^{+}$co-exposed group. This data suggests that inducing HO-1 levels increases cellular viability and, thus, confers protection to SH-SY5Y cells. Our results are in agreement with earlier reports wherein induction of HO-1 in cells has been shown to confer protection to cells against oxidative stress [35-37].

ROS have multiple effects on cell function, depending on the amount and subcellular location of the ROS generated [38]. Some studies have reported that ROS are involved in the apoptotic mechanism of $\mathrm{MPP}^{+}$-mediated neurotoxicity $[39,40]$. p53 is a key modulator of cellular stress responses and is thought to mediate apoptosis in several neurodegenerative diseases, including PD [41]. Furthermore, it has been reported to play a prominent role in mediating cell death in several experimental models of PD [42-44]. Since SH-SY5Y cells express wild-type p53 [45], they are suitable for investigating regulation and functions of this protein. p53 is a tumor suppressor protein that is present at low concentrations in normal cells. However, when cells are subjected to stress and injury, protein levels of p53 are increased, leading to apoptosis [46]. It has been reported that $\mathrm{MPP}^{+}$induces apoptosis through the activation of the p53 pathway [43]. To determine whether ATR-I pre-treatment had any effect on the levels of p53, Western blot analysis of total lysates was performed. Our results indicated that pre-treatment with ATR-I significantly diminished the protein levels of p53 in $\mathrm{MPP}^{+}$stimulated in SH-SY5Y cells. Bax is a proapoptotic member of the Bcl-2 family and is also the target gene for p53, which is closely associated to mediate cell death in PD $[47,48]$. On the other hand, the Bcl-2 family of proteins is involved in positive and negative regulation of apoptotic cell death [49]. O'Malley et al. [50] reported that the over-expression of Bcl-2 attenuates $\mathrm{MPP}^{+}$-induced cell death. Bcl-2 and Bax collectively control the permeability of mitochondrial transition pore that results in apoptosis $[44,51,52]$. Cell survival in the early phases of the apoptotic cascade depends mostly on the balance between the pro- and anti-apoptotic proteins of the Bcl-2 family. In this regard, the Bax/Bcl-2 mRNA ratio 
may be a better predictor of apoptotic fate than the absolute concentrations of either Bax or Bcl-2 alone [53]. In our study, exposure to $\mathrm{MPP}^{+}$led to significant upregulation of Bax mRNA expression and diminished Bcl-2 mRNA expression in SH-SY5Y cells. Consequently, the ratio of the Bax/Bcl-2 mRNA increased significantly upon treatment with $\mathrm{MPP}^{+}$. However, pre-treatment with ATR-I significantly decreased the Bax/Bcl-2 mRNA ratio in $\mathrm{MPP}^{+}$-stimulated SH-SY5Y cells.

$\mathrm{MPP}^{+}$-induced ROS and Bax have been documented to affect the mitochondrial permeability pore and, thereby, release cytochrome-c in the cytoplasm which further combines with apoptosis activating factor (Apaf-1) and procaspase-9 to further activate caspase-3 [17,54]. It has been reported that caspase- 3 acts as an apoptotic executor in both pathways by activating DNA fragmentation to cause apoptotic cell death and decrease in caspase- 3 activity is associated with a decrease in the $\mathrm{Bax} / \mathrm{Bcl}-2$ ratio [55]. In our study, exposure of $\mathrm{MPP}^{+}$to SH-SY5Y cells considerably increased protein expression of cytochrome-c and caspase-3. Our results are in accordance with an earlier report by Doo et al. wherein suppression of cytochrome-c and caspase-3 expression provide protective effects against $\mathrm{MPP}^{+}$-induced apoptosis in SH-SY5Y cells. It has also been reported that activation of caspase-3 leads to the cleavage of a number of proteins, including PARP [16,56]. PARP, one of downstream targets of caspase-3, is an abundant nuclear enzyme that normally takes part in DNA repair, but extensive PARP activation can promote cell death [57]. In this study, ATR-I pre-treatment was found to reduce the cleavage of PARP in $\mathrm{MPP}^{+}$-intoxicated SH-SY5Y cells. These observations imply that ATR-I may modulate the expression of $\mathrm{Bax} / \mathrm{Bcl}-2$ mRNA in response to $\mathrm{MPP}^{+}$treatment, regulating a succession of mitochondria-mediated downstream molecular events including the caspase-3 activation and PARP proteolysis.

\section{Materials and Methods}

\subsection{Reagents and Antibodies}

ATR-I (purity $\geq 98 \%$ ) was purchased from Baoji Herbest Bio-Tech Co., Ltd. (Baoji, China). MPP ${ }^{+}$, 3-(3,4-dimehylthiazol-2-yl)-2,5-diphenyl-tetrazolium bromide (MTT), and ZnPP-IX were obtained from Sigma-Aldrich (St. Louis, MO, USA). Six-well and 96-well tissue culture plates and $100 \mathrm{~mm}$ culture dishes were purchased from Nunc Inc. (North Aurora Road, Naperville, IL, USA). Dulbecco's modified Eagle's medium (DMEM/F12 + Glutamax) and fetal bovine serum (FBS) were obtained from Gibco-BRL Technologies (Gaithersburg, MD, USA). The antibody for p53 and cytochrome-c were procured from Santa Cruz Biotechnology (Santa Cruz, CA, USA). Antibodies for caspase-3, cleaved PARP, and $\beta$-actin were obtained from Cell Signaling Co. (Boston, MA, USA). The antibody for HO-1 was obtained from Enzo Life Sciences (Farmingdale, NY, USA). All other chemicals used in this study were of analytical grade and were obtained, unless otherwise noted, from Sigma-Aldrich.

\subsection{Cell Culture and Treatments}

The human dopaminergic neuroblastoma cell line, SH-SY5Y, was purchased from American Type Culture Collection (ATCC) (Manassas, VA, USA). SH-SY5Y cells were cultured in DMEM/F12 + Glutamax supplemented with $10 \%(v / v)$ inactivated fetal bovine serum, and $100 \mathrm{U} / \mathrm{mL}$ penicillin/streptomycin. The cells were maintained at $37{ }^{\circ} \mathrm{C}$ in a $5 \% \mathrm{CO}_{2}$ and $95 \%$ humidified air incubator for the indicated time. ATR-I was dissolved in dimethyl sulfoxide (DMSO). The control group was treated with only DMSO (vehicle group).

\subsection{Measurement of Cell Viability}

Viability of cultured cells was measured by the reduction of MTT to formazan [58]. SH-SY5Y cells $\left(2.5 \times 10^{4}\right.$ cells $\left./ \mathrm{mL}\right)$ were pre-treated with different doses of ATR-I $(1,5,25,50$, and $100 \mu \mathrm{M})$ for $2 \mathrm{~h}$ in 96-well plates and then stimulated with or without $\mathrm{MPP}^{+}(2 \mathrm{mM})$ for $24 \mathrm{~h}$. After the treatment for $24 \mathrm{~h}$, the medium was removed and the cells were incubated with $0.5 \mathrm{mg} / \mathrm{mL}$ of MTT solution for $4 \mathrm{~h}$ at $37^{\circ} \mathrm{C}$. The supernatant was carefully removed, and the formed formazan crystals were dissolved 
in DMSO and the absorbance at $550 \mathrm{~nm}$ was measured using a microplate reader. Cell viability was expressed as a percentage of the control (untreated cells).

\subsection{Isolation of Total RNA and Reverse Transcription Polymerase Chain Reaction (RT-PCR)}

SH-SY5Y cells seeded in six-well plates $\left(50 \times 10^{4}\right.$ cells $\left./ \mathrm{mL}\right)$ were pretreated with ATR-I $(1$, 5 , and $25 \mu \mathrm{M}$ ) for $2 \mathrm{~h}$ and then exposed with or without $2 \mathrm{mM} \mathrm{MPP}^{+}$for $6 \mathrm{~h}$. Total RNA was isolated by extraction with TRIzol (Invitrogen) (Burlington, ON, Canada). For the reverse transcription-polymerase chain reaction (RT-PCR), $2.5 \mu \mathrm{g}$ of total RNA from each group was reverse-transcribed using a First-Strand cDNA synthesis kit (Invitrogen). Then, cDNA was amplified by PCR using specific primers, as mentioned previously [59]. The PCR was performed using the above-prepared cDNA as a template for respective targets. The following primers were used for PCR: Bax: F-5'-CACCAAGGTGCCGGAACTGA-3' and R-5'-AATGCCCATGTCCCCCAAT-3'; BcL-2: F-5'-ACGACTTCTCCCGCCGCTAC-3' and R-5'-CCCAGCCTCCGTTATCCTGG-3'; HO-1: F-5'-CACGCCTACACCCGCTACCT- $3^{\prime}$ and R-5'-TCTGTCACCCTGTGCTTGAC- ${ }^{\prime}$; and GAPDH: F-5'-GTCAGTGGTGGACCTGACCT- $3^{\prime}$ and F-5'-GTCAGTGGTGGACCTGACCT- ${ }^{\prime}$. PCR products were analyzed on $1 \%$ agarose gels stained with ethidium bromide, and bands were visualized by UV light.

\subsection{Sodium Dodecyl Sulfate-Polyacrylamide Gel Electrophoresis (SDS-PAGE) and Western Blot Analysis}

SH-SY5Y cells $\left(50 \times 10^{4}\right.$ cells $\left./ \mathrm{mL}\right)$ cultured in six-well plates were pretreated when the cell confluency was $75 \%$ without or with ATR-I $(1,5$, and $25 \mu \mathrm{M})$ for $2 \mathrm{~h}$, followed by treatment with LPS for $18 \mathrm{~h}$. Preparation of cell lysates and electrophoresis and immunoblotting procedures followed a previous report [59]. PVDF membranes were labeled with respective antibodies by incubating them overnight with anti-p53 (1:1000), anti-cytochrome-c (1:1000), anti-caspase-3 (1:1000), anti-cleaved PARP (1:1000), anti-TH (1:1000), anti-HO-1 (1:1000), and anti- $\beta$-actin (1:2000) antibodies, followed by a $1 \mathrm{~h}$ incubation with horseradish peroxidase-conjugated secondary antibodies (1:1000-1:5000) (Cell Signaling Technology) (Danvers, MA, USA) and (Santa Cruz biotechnology). The optical densities of the antibody-specific bands were analyzed with a Luminescent Image Analyzer, LAS-3000 (Fuji, Tokyo, Japan).

\subsection{Statistical Analyses}

Statistical analyses were performed using GraphPad software, version 5 (GraphPad, La Jolla, CA, USA). Data are expressed as means \pm standard error (SEM) of at least three independent experiments. Significant differences between the groups were determined using a one-way analysis of variance (ANOVA) followed by Tukey's post hoc analysis. $p$-values $<0.05$ were considered statistically significant.

\section{Conclusions}

In summary (Figure 6), our results show that pre-treatment of SH-SY5Y cells with ATR-I significantly decreases $\mathrm{MPP}^{+}$-induced apoptotic cell death. This anti-apoptotic effect is a result of diminished caspase- 3 and cleaved PARP release that subsequently abates pro-apoptotic signaling in the mitochondria, thereby decreasing cell death. Additionally, ATR-I by its anti-oxidant effect, evident by the upregulation of HO-1 release, might also contribute to the cytoprotective effect in SH-SY5Y cells. Our study reports that ATR-I could ameliorate $\mathrm{MPP}^{+}$-induced oxidative stress and apoptosis in SH-SY5Y cells and exert its neuroprotective activity partly by decreasing oxidative stress and by inhibiting pro-apoptotic signals. 


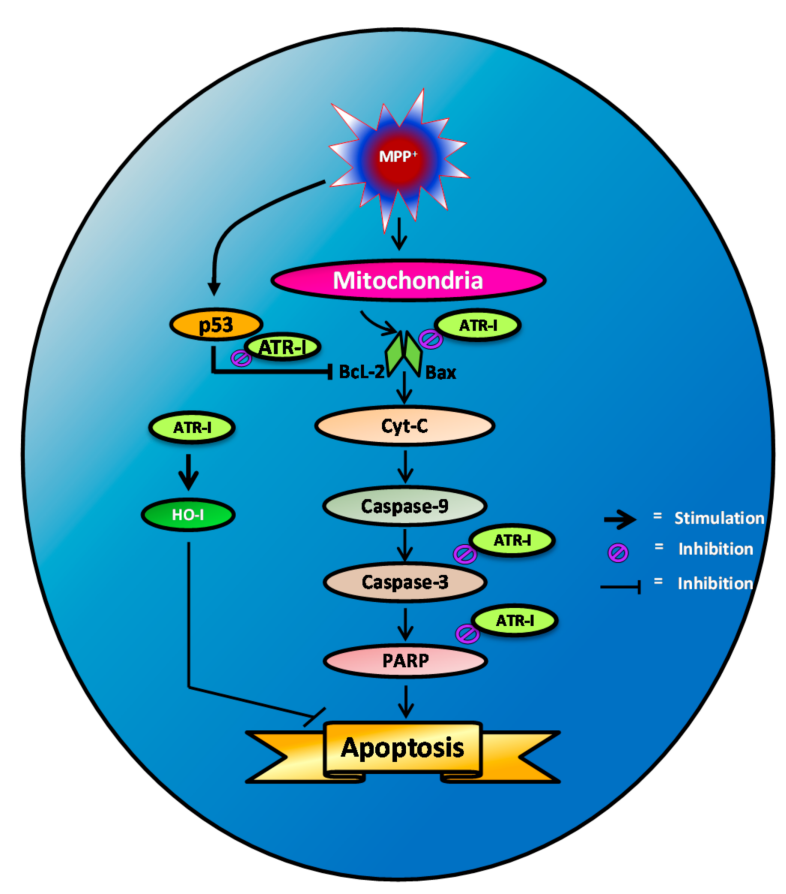

Figure 6. Scheme representing $\mathrm{MPP}^{+}$-induced apoptotic signaling

Acknowledgments: This paper was supported by Konkuk University in 2016.

Author Contributions: Sandeep Vasant More conducted the experimentation, analysis, and preparation of the manuscript. Dong-Kug Choi selected the topic and finely edited the manuscript.

Conflicts of Interest: The authors declare no conflict of interest.

$\begin{array}{ll}\text { Abbreviations } \\ \text { ATR-I } & \text { Atractylenolide-I } \\ \text { Apaf } & \text { Apoptotic protease activating factor 1 } \\ \text { DMSO } & \text { Dimethyl sulfoxide } \\ \text { HO-1 } & \text { Oxygenase-1 } \\ \text { MPP } & \text { 1-methyl-4-phenylpyridinium } \\ \text { MPTP } & \text { 1-methyl-4-phenyl-1,2,3,6-tetrahydropyridine } \\ \text { PD } & \text { Parkinson's disease } \\ \text { PARP } & \text { (ADP-ribose) polymerase } \\ \text { PCD } & \text { Programmed cell death } \\ \text { ROS } & \text { Reactive oxygen species } \\ \text { SN } & \text { Substantia nigra } \\ \text { ZnPP } & \text { Zinc protoporphyrin }\end{array}$

\section{References}

1. Henchcliffe, C.; Beal, M.F. Mitochondrial biology and oxidative stress in parkinson disease pathogenesis. Nat. Clin. Pract. Neurol. 2008, 4, 600-609. [CrossRef] [PubMed]

2. Imaizumi, Y.; Okada, Y.; Akamatsu, W.; Koike, M.; Kuzumaki, N.; Hayakawa, H.; Nihira, T.; Kobayashi, T.; Ohyama, M.; Sato, S.; et al. Mitochondrial dysfunction associated with increased oxidative stress and alpha-synuclein accumulation in PARK2 IPSC-derived neurons and postmortem brain tissue. Mol. Brain 2012, 5, 35. [CrossRef] [PubMed]

3. Licker, V.; Turck, N.; Kovari, E.; Burkhardt, K.; Cote, M.; Surini-Demiri, M.; Lobrinus, J.A.; Sanchez, J.C.; Burkhard, P.R. Proteomic analysis of human substantia nigra identifies novel candidates involved in Parkinson's disease pathogenesis. Proteomics 2014, 14, 784-794. [CrossRef] [PubMed] 
4. Leist, M.; Jaattela, M. Four deaths and a funeral: From caspases to alternative mechanisms. Nat. Rev. Mol. Cell Biol. 2001, 2, 589-598. [CrossRef] [PubMed]

5. Gonzalez-Burgos, E.; Fernandez-Moriano, C.; Gomez-Serranillos, M.P. Potential neuroprotective activity of ginseng in Parkinson's disease: A review. J. Neuroimmune Pharmacol. 2014. [CrossRef] [PubMed]

6. Kost, G.C.; Selvaraj, S.; Lee, Y.B.; Kim, D.J.; Ahn, C.H.; Singh, B.B. Clavulanic acid inhibits MPP+-induced ROS generation and subsequent loss of dopaminergic cells. Brain Res. 2012, 1469, 129-135. [CrossRef] [PubMed]

7. Przedborski, S.; Jackson-Lewis, V. Mechanisms of mptp toxicity. Mov. Disord. 1998, 13, S35-S38.

8. Singer, T.P.; Ramsay, R.R. Mechanism of the neurotoxicity of mptp. An update. FEBS Lett. 1990, $274,1-8$. [PubMed]

9. Dykens, J.A. Isolated cerebral and cerebellar mitochondria produce free radicals when exposed to elevated $\mathrm{Ca}^{2+}$ and $\mathrm{Na}^{+}$: Implications for neurodegeneration. J. Neurochem. 1994, 63, 584-591. [CrossRef] [PubMed]

10. Perier, C.; Tieu, K.; Guegan, C.; Caspersen, C.; Jackson-Lewis, V.; Carelli, V.; Martinuzzi, A.; Hirano, M.; Przedborski, S.; Vila, M. Complex I deficiency primes Bax-dependent neuronal apoptosis through mitochondrial oxidative damage. Proc. Natl. Acad. Sci. USA 2005, 102, 19126-19131. [CrossRef] [PubMed]

11. Seaton, T.A.; Cooper, J.M.; Schapira, A.H. Free radical scavengers protect dopaminergic cell lines from apoptosis induced by complex I inhibitors. Brain Res. 1997, 777, 110-118. [PubMed]

12. Blum, D.; Torch, S.; Lambeng, N.; Nissou, M.; Benabid, A.L.; Sadoul, R.; Verna, J.M. Molecular pathways involved in the neurotoxicity of 6-OHDA, dopamine and MPTP: Contribution to the apoptotic theory in Parkinson's disease. Prog. Neurobiol. 2001, 65, 135-172. [CrossRef]

13. Zhang, Y.; Dawson, V.L.; Dawson, T.M. Oxidative stress and genetics in the pathogenesis of Parkinson's disease. Neurobiol. Dis. 2000, 7, 240-250. [CrossRef] [PubMed]

14. Marchetti, B.; Abbracchio, M.P. To be or not to be (inflamed)—Is that the question in anti-inflammatory drug therapy of neurodegenerative disorders? Trends Pharmacol. Sci. 2005, 26, 517-525. [CrossRef] [PubMed]

15. Chaitanya, G.V.; Steven, A.J.; Babu, P.P. PARP-1 cleavage fragments: Signatures of cell-death proteases in neurodegeneration. Cell Commun. Signal. 2010, 8, 31. [CrossRef] [PubMed]

16. King, T.D.; Bijur, G.N.; Jope, R.S. Caspase-3 activation induced by inhibition of mitochondrial complex I is facilitated by glycogen synthase kinase-3 $\beta$ and attenuated by lithium. Brain Res. 2001, 919, 106-114. [CrossRef]

17. Mattson, M.P. Apoptosis in neurodegenerative disorders. Nat. Rev. Mol. Cell Biol. 2000, 1, 120-129. [CrossRef] [PubMed]

18. Kao, T.-K.; Ou, Y.-C.; Lin, S.-Y.; Pan, H.-C.; Song, P.-J.; Raung, S.-L.; Lai, C.-Y.; Liao, S.-L.; Lu, H.-C.; Chen, C.-J. Luteolin inhibits cytokine expression in endotoxin/cytokine-stimulated microglia. J. Nutr. Biochem. 2011, 22, 612-624. [CrossRef] [PubMed]

19. Park, J.H.; Lee, H.J.; Koh, S.B.; Ban, J.Y.; Seong, Y.H. Protection of NMDA-induced neuronal cell damage by methanol extract of Zizyphi Spinosi Semen in cultured rat cerebellar granule cells. J. Ethnopharmacol. 2004, 95, 39-45. [CrossRef] [PubMed]

20. Lahlou, M. The success of natural products in drug discovery. Pharmacol. Pharm. 2013, 4, 17. [CrossRef]

21. Zhang, Y.; Xu, S.; Lin, Y. Gastrointestinal inhibitory effects of sesquiterpene lactones from atractylodes macrocephala. Zhong Yao Cai 1999, 22, 636-640. [PubMed]

22. Wang, Y.; Chang, J.; Li, K.; Wu, C.; Tin, K.; Liu, Y. Studies on the constituents of atractylodes macrocephala koidz. Shanzi Med. J. 1980, 9, 47-51.

23. Li, C.-Q.; He, L.-C.; Dong, H.-Y.; Jin, J.-Q. Screening for the anti-inflammatory activity of fractions and compounds from Atractylodes macrocephala koidz. J. Ethnopharmacol. 2007, 114, 212-217. [CrossRef] [PubMed]

24. Huang, H.-L.; Chen, C.-C.; Yeh, C.-Y.; Huang, R.-L. Reactive oxygen species mediation of baizhu-induced apoptosis in human leukemia cells. J. Ethnopharmacol. 2005, 97, 21-29. [CrossRef] [PubMed]

25. Kirkman, M.A.; Tyrrell, P.J.; King, A.T.; Patel, H.C. Imaging in young adults with intracerebral hemorrhage. Clin. Neurol. Neurosurg. 2012, 114, 1297-1303. [CrossRef] [PubMed]

26. Gao, M.; Zhang, W.C.; Liu, Q.S.; Hu, J.J.; Liu, G.T.; Du, G.H. Pinocembrin prevents glutamate-induced apoptosis in SH-SY5Y neuronal cells via decrease of Bax/Bcl-2 ratio. Eur. J. Pharmacol. 2008, 591, 73-79. [CrossRef] [PubMed]

27. Brentnall, M.; Rodriguez-Menocal, L.; De Guevara, R.L.; Cepero, E.; Boise, L.H. Caspase-9, caspase-3 and caspase-7 have distinct roles during intrinsic apoptosis. BMC Cell Biol. 2013, 14, 32. [CrossRef] [PubMed] 
28. Suh, D.H.; Kim, M.K.; Kim, H.S.; Chung, H.H.; Song, Y.S. Mitochondrial permeability transition pore as a selective target for anti-cancer therapy. Front. Oncol. 2013, 3, 41. [CrossRef] [PubMed]

29. Robert, G.; Puissant, A.; Dufies, M.; Marchetti, S.; Jacquel, A.; Cluzeau, T.; Colosetti, P.; Belhacene, N.; Kahle, P.; da Costa, C.A.; et al. The caspase 6 derived N-terminal fragment of DJ-1 promotes apoptosis via increased ROS production. Cell Death Differ. 2012, 19, 1769-1778. [CrossRef] [PubMed]

30. Lu, J.; Park, C.S.; Lee, S.K.; Shin, D.W.; Kang, J.H. Leptin inhibits 1-methyl-4-phenylpyridinium-induced cell death in SH-SY5Y cells. Neurosci. Lett. 2006, 407, 240-243. [CrossRef] [PubMed]

31. Mena, N.P.; Urrutia, P.J.; Lourido, F.; Carrasco, C.M.; Nunez, M.T. Mitochondrial iron homeostasis and its dysfunctions in neurodegenerative disorders. Mitochondrion 2015, 21, 92-105. [CrossRef] [PubMed]

32. Fall, C.P.; Bennett, J.P. Characterization and time course of MPP ${ }^{+}$-induced apoptosis in human SH-SY5Y neuroblastoma cells. J. Neurosci. Res. 1999, 55, 620-628. [CrossRef]

33. Brouard, S.; Otterbein, L.E.; Anrather, J.; Tobiasch, E.; Bach, F.H.; Choi, A.M.; Soares, M.P. Carbon monoxide generated by heme oxygenase 1 suppresses endothelial cell apoptosis. J. Exp. Med. 2000, 192, 1015-1026. [CrossRef] [PubMed]

34. Parfenova, H.; Basuroy, S.; Bhattacharya, S.; Tcheranova, D.; Qu, Y.; Regan, R.F.; Leffler, C.W. Glutamate induces oxidative stress and apoptosis in cerebral vascular endothelial cells: Contributions of HO-1 and HO-2 to cytoprotection. Am. J. Physiol. Cell Physiol. 2006, 290, C1399-C1410. [CrossRef] [PubMed]

35. Samoylenko, A.; Dimova, E.Y.; Horbach, T.; Teplyuk, N.; Immenschuh, S.; Kietzmann, T. Opposite expression of the antioxidant heme oxygenase- 1 in primary cells and tumor cells: Regulation by interaction of USF-2 and Fra-1. Antioxid. Redox Signal. 2008, 10, 1163-1174. [CrossRef] [PubMed]

36. Dal-Cim, T.; Molz, S.; Egea, J.; Parada, E.; Romero, A.; Budni, J.; Martin de Saavedra, M.D.; del Barrio, L.; Tasca, C.I.; Lopez, M.G. Guanosine protects human neuroblastoma SH-SY5Y cells against mitochondrial oxidative stress by inducing heme oxigenase-1 via PI3K/Akt/GSK-3 $\beta$ pathway. Neurochem. Int. 2012, 61, 397-404. [CrossRef] [PubMed]

37. Li, M.H.; Cha, Y.N.; Surh, Y.J. Peroxynitrite induces HO-1 expression via PI3K/Akt-dependent activation of Nf-E2-related factor 2 in PC12 cells. Free Radical Biol. Med. 2006, 41, 1079-1091. [CrossRef] [PubMed]

38. Biswas, S.; Chida, A.S.; Rahman, I. Redox modifications of protein-thiols: Emerging roles in cell signaling. Biochem. Pharmacol. 2006, 71, 551-564. [CrossRef] [PubMed]

39. Alberio, T.; Lopiano, L.; Fasano, M. Cellular models to investigate biochemical pathways in Parkinson's disease. FEBS J. 2012, 279, 1146-1155. [CrossRef] [PubMed]

40. Baltazar, M.T.; Dinis-Oliveira, R.J.; de Lourdes Bastos, M.; Tsatsakis, A.M.; Duarte, J.A.; Carvalho, F. Pesticides exposure as etiological factors of Parkinson's disease and other neurodegenerative diseases-A mechanistic approach. Toxicol. Lett. 2014, 230, 85-103. [CrossRef] [PubMed]

41. Culmsee, C.; Mattson, M.P. p53 in neuronal apoptosis. Biochem. Biophys. Res. Commun. 2005, 331, 761-777. [CrossRef] [PubMed]

42. Trimmer, P.A.; Smith, T.S.; Jung, A.B.; Bennett, J.P., Jr. Dopamine neurons from transgenic mice with a knockout of the $p 53$ gene resist MPTP neurotoxicity. Neurodegeneration 1996, 5, 233-239. [CrossRef] [PubMed]

43. Duan, W.; Zhu, X.; Ladenheim, B.; Yu, Q.S.; Guo, Z.; Oyler, J.; Cutler, R.G.; Cadet, J.L.; Greig, N.H.; Mattson, M.P. p53 inhibitors preserve dopamine neurons and motor function in experimental parkinsonism. Ann. Neurol. 2002, 52, 597-606. [CrossRef] [PubMed]

44. Perier, C.; Bove, J.; Wu, D.C.; Dehay, B.; Choi, D.K.; Jackson-Lewis, V.; Rathke-Hartlieb, S.; Bouillet, P.; Strasser, A.; Schulz, J.B.; et al. Two molecular pathways initiate mitochondria-dependent dopaminergic neurodegeneration in experimental Parkinson's disease. Proc. Natl. Acad. Sci. USA 2007, 104, 8161-8166. [CrossRef] [PubMed]

45. Ronca, F.; Chan, S.L.; Yu, V.C. 1-(5-isoquinolinesulfonyl)-2-methylpiperazine induces apoptosis in human neuroblastoma cells, SH-SY5Y, through a p53-dependent pathway. J. Biol. Chem. 1997, 272, 4252-4260. [CrossRef] [PubMed]

46. Sanz, E.; Quintana, A.; Battaglia, V.; Toninello, A.; Hidalgo, J.; Ambrosio, S.; Valoti, M.; Marco, J.L.; Tipton, K.F.; Unzeta, M. Anti-apoptotic effect of Mao-B inhibitor PF9601N [N-(2-propynyl)-2(5-benzyloxy-indolyl) methylamine] is mediated by p53 pathway inhibition in MPP ${ }^{+}$-treated SH-SY5Y human dopaminergic cells. J. Neurochem. 2008, 105, 2404-2417. [CrossRef] [PubMed]

47. Miyashita, T.; Reed, J.C. Tumor suppressor p53 is a direct transcriptional activator of the human bax gene. Cell 1995, 80, 293-299. [PubMed] 
48. Hartmann, A.; Michel, P.P.; Troadec, J.D.; Mouatt-Prigent, A.; Faucheux, B.A.; Ruberg, M.; Agid, Y.; Hirsch, E.C. Is Bax a mitochondrial mediator in apoptotic death of dopaminergic neurons in Parkinson's disease? J. Neurochem. 2001, 76, 1785-1793. [CrossRef] [PubMed]

49. Gross, A.; McDonnell, J.M.; Korsmeyer, S.J. Bcl-2 family members and the mitochondria in apoptosis. Gene Dev. 1999, 13, 1899-1911. [CrossRef] [PubMed]

50. O'Malley, K.L.; Liu, J.; Lotharius, J.; Holtz, W. Targeted expression of Bcl-2 attenuates MPP but not 6-OHDA induced cell death in dopaminergic neurons. Neurobiol. Dis. 2003, 14, 43-51. [CrossRef]

51. McDonnell, T.J.; Beham, A.; Sarkiss, M.; Andersen, M.M.; Lo, P. Importance of the Bcl-2 family in cell death regulation. Experientia 1996, 52, 1008-1017. [CrossRef] [PubMed]

52. Miller, T.M.; Moulder, K.L.; Knudson, C.M.; Creedon, D.J.; Deshmukh, M.; Korsmeyer, S.J.; Johnson, E.M., Jr. Bax deletion further orders the cell death pathway in cerebellar granule cells and suggests a caspase-independent pathway to cell death. J. Cell. Biol. 1997, 139, 205-217. [CrossRef] [PubMed]

53. Cory, S.; Adams, J.M. The Bcl2 family: Regulators of the cellular life-or-death switch. Nat. Rev. Cancer 2002, 2, 647-656. [CrossRef] [PubMed]

54. Marnett, L.J.; Riggins, J.N.; West, J.D. Endogenous generation of reactive oxidants and electrophiles and their reactions with DNA and protein. J. Clin. Investig. 2003, 111, 583-593. [CrossRef] [PubMed]

55. Doo, A.R.; Kim, S.N.; Kim, S.T.; Park, J.Y.; Chung, S.H.; Choe, B.Y.; Chae, Y.; Lee, H.; Yin, C.S.; Park, H.J. Bee venom protects SH-SY5Y human neuroblastoma cells from 1-methyl-4-phenylpyridinium-induced apoptotic cell death. Brain Res. 2012, 1429, 106-115. [CrossRef] [PubMed]

56. Kanthasamy, A.G.; Anantharam, V.; Zhang, D.; Latchoumycandane, C.; Jin, H.; Kaul, S.; Kanthasamy, A. A novel peptide inhibitor targeted to caspase- 3 cleavage site of a proapoptotic kinase protein kinase c $\delta$ (PKC $\delta$ ) protects against dopaminergic neuronal degeneration in Parkinson's disease models. Free Radic. Biol. Med. 2006, 41, 1578-1589. [CrossRef] [PubMed]

57. Le, D.A.; Wu, Y.; Huang, Z.; Matsushita, K.; Plesnila, N.; Augustinack, J.C.; Hyman, B.T.; Yuan, J.; Kuida, K.; Flavell, R.A.; et al. Caspase activation and neuroprotection in caspase-3-deficient mice after in vivo cerebral ischemia and in vitro oxygen glucose deprivation. Proc. Natl. Acad. Sci. USA 2002, 99, 15188-15193. [CrossRef] [PubMed]

58. Datki, Z.; Juhasz, A.; Galfi, M.; Soos, K.; Papp, R.; Zadori, D.; Penke, B. Method for measuring neurotoxicity of aggregating polypeptides with the mtt assay on differentiated neuroblastoma cells. Brain Res. Bull. 2003, 62, 223-229. [CrossRef] [PubMed]

59. More, S.V.; Park, J.Y.; Kim, B.W.; Kumar, H.; Lim, H.W.; Kang, S.M.; Koppula, S.; Yoon, S.H.; Choi, D.K. Anti-neuroinflammatory activity of a novel cannabinoid derivative by inhibiting the NF-K signaling pathway in lipopolysaccharide-induced BV-2 microglial cells. J. Pharmacol. Sci. 2013, 121, 119-130. [CrossRef] [PubMed]

(c) 2017 by the authors. Licensee MDPI, Basel, Switzerland. This article is an open access article distributed under the terms and conditions of the Creative Commons Attribution (CC BY) license (http://creativecommons.org/licenses/by/4.0/). 